\title{
Hepatitis C Viral Load Measurement
}

National Cancer Institute

\section{Source}

National Cancer Institute. Hepatitis C Viral Load Measurement. NCI Thesaurus. Code C92543.

The determination of the HCV viral load in a specimen. 